\title{
Beyond conventional counterterrorism strategy: Prospects and challenges of community and vigilante groups' policing in Africa
}

\author{
BOLAJI OMITOLA \\ PH.D., PROFESSOR \\ ORCID: 0000-0001-8114-5516 \\ Department of Political Sciences, Osun State University, Nigeria \\ e-mail: bolaji.omitola@uniosun.edu.ng
}

\section{OlaWALE Olufemi AKINRINDE LECTURER II \\ ORCID: 0000-0001-7350-2376 \\ Department of Political Sciences, Osun State University, Nigeria e-mail: olawale.akinrinde@uniosun.edu.ng}

\author{
VICTOR FAKOYA \\ PH.D. \\ ORCID: 0000-0003-3905-6776 \\ Department of Political Science, University of Nevada, Las Vegas, United States of America \\ e-mail: victor.fakoya@unlv.edu
}

\author{
USMAN TAR \\ PH.D., PROFESSOR \\ ORCID: 0000-0001-8471-1034 \\ Department of Political Science and Defence Studies \\ Nigerian Defence Academy, Nigeria \\ e-mail: uatar@nda.edu.ng
}

Keywords: $\quad$ terrorism, counterterrorism, conventional counterterrorism strategy, Community and Vigilante-Group Policing, Africa 
Abstract Evidences from counterterrorism and the war on terrorism operations in Africa have revealed the inadequacies of the conventional counterterrorism strategy. The over-reliance on the use of simply hard-military and offensive strategy in prosecuting the war against terrorism and forms of insurgencies in Africa since the inception of the war on terrorism and counterterrorism in Africa has largely been counterproductive. From Boko Haram in Nigeria to the Islamic State of West African Province in West Africa (ISWAP), to Al-Shabab in eastern parts of Africa, and then to Al-Qaeda in the Islamic Maghreb (AQIM), the rise and spike in terrorism in Africa remains indirectly proportionate to the conventional counterterrorism operations and strategy. The deficiency of the use of conventional counterterrorism strategy in the prosecution of war on terrorism in Africa, coupled with its flawed outcome, has ignited calls for alternative counterterrorism strategies. Chief amongst these alternative counterterrorism strategies is the Community and Vigilante-Group Policing in Africa which emboldens culture, language, episteme, authority, and interest of the people in quest to address the scourge of terrorism and other security threats. This article is therefore an attempt to unpack the prospects and side-effects of the Community and Vigilante-Group Policing as an alternative counterterrorism strategy in the war on terrorism in Africa.

\section{Introduction}

This article interrogates the inevitability of softer strategies for winning the war on terrorism in Africa. The authors argue that adequate attention should be placed on socio-cultural factors, including social structure, culture, language, power and authority, and interest of the people which are indubitably vital to winning a counterterrorism war (Nagl et al., 2008). This approach is pursued in order to understand and appreciate the nature of terrorism as a public threat as against a national security threat (Gurski, 2018). Additionally, there is a need for gradual shift from military involvement to policing. Such policing will not only be organised around people's participation but shall involve the locals, adopting sustainable policing strategy for overall legitimacy and ownership. The inevitability of the shift of focus away from war on terror to policing is further predicated on the nature of African societies with its myriad of diversities that are easily exploited by various terrorist groups operating on the continent. Thus, the people, through their agency like vigilante groups are put forward as a reliable partner within a context of checks and balances in order to ensure standardisation and best practices in policing terrorism in Africa.

For analytical purpose, the article is divided into eight sections. This introductory section is followed by explanation of major concepts that are employed in this article: terrorism, counterterrorism and security. The third section sets the theoretical framework for the article by exploring the issues of security and securitization and their relationship with counterterrorism, especially counterterrorism policy with emphasis on policing involving community and indigenous efforts. The fourth section reviews the conventional war on terror as led by the United States of America and its shortcomings, especially in Africa. The fifth section establishes the basis for alternative security culture for counterterrorism in Africa while the sixth section examines the roles of the community, the people, and vigilante groups in policing terror. The seventh section interrogates the envisaged challenges and means of overtaking such challenges while the last section is the conclusion. 


\section{Terrorism, counterterrorism and security: Conceptual clarifications}

Terrorism is "a special type of political violence which is a public threat" (Lewis, 2017). However, there is lack of agreement on its definition so much that there is a common observation that “one's person's terrorist is another freedom fighter". Therefore, scholars define terrorism based on individual preferences, beliefs, and political, religious or cultural orientations.

According to United States' Federal Bureau of Investigation, terrorism can be in two types: (1) international terrorism which refers to violent, criminal acts committed by individuals and/ or groups who are inspired by, or associated with, designated foreign terrorist organizations or nations (state-sponsored), and (2) domestic terrorism which refers to violent, criminal acts committed by individuals and/or groups to further ideological goals stemming from domestic influences, such as those of a political, religious, social, racial, or environmental nature (Federal Bureau of Investigations, 2020).

According to another definition, offered by Barash and Webel (2009), terrorism involves a premeditated, usually politically motivated, use, or threatened use, of violence, to instill a state of fear in its victims, usually for the purpose of influencing another, less reachable audience, such as a government. Such victims may include civilian non-combatants but are not necessarily limited to them (Barash, Webel, 2009).

Various dimensions of terrorism have been summarised by International Criminal Police Organization. These include the following: organized terrorism in conflict zones, foreign terrorist fighters, radicalized "lone wolves", and attacks using chemical, biological, radiological, nuclear, and explosive materials. It is also observed that social media have been used extensively by terrorists for radicalization, recruitment, funding, planning, and execution of terror activities (Interpol, 2020). Counterterrorism has to do with the mobilisation of a country's national security architecture to deflect and ward off terrorism. For Lewis (2017, p. 11), counterterrorism is an act that seeks to provide non-combatants with physical, physiological, and political security. Furthermore, counterterrorism is an intentional act that has three possible goals: the countering of deliberately indiscriminate violence, of threats of indiscriminate violence, and of political demands made via threats of indiscriminate violence (Lewis, 2017, p. 20). Counterterrorism has indeed taken diverse forms. For Gurski (2018, p. 1), these strategies include: invasion and occupation, airstrikes, and the use of drones; the use of intermediaries; and the use of Special Forces. However, like the debate on security, the emphasis now is on what is referred to as "softer" strategies in counterterrorism. Soft power refers to "the ability to get what you want through attraction rather than coercion or payment" (Nye, 2004, p.115). In other words, military role in counterterrorism must be measured and limited, (Gurski, 2018, p. 2) and to allow for sustainability, the locals must be involved directly. This is the point at which counterterrorism can be described as attempts at securing a country from all forms of attacks, both internal and external. So, we turn to definition of security.

Security has been defined by Cambridge English Dictionary as "protection of a person, building, organisation or country against threat such as crime or attacks by foreign countries; the protection of people, organisation, countries, etc. against a possible attack or other crime". 
Security implies freedom from, or elimination of, threat not only to the physical existence of the state, but also to its (state's) ability to protect the generality of its citizenry and provide a congenial environment for the development of their well-being (Ejiogba, 2006, p. 303).

In recent times, the emphasis has been put on human security, because of the realisation that a sustainable security should drive the counterterrorism strategy in Africa and must combine development, human rights, and security concerns. Such security culture must also close the agelong and colonial inherited distance between security regime and ordinary people to allow for legitimacy, ownership participation, and sustainability of the fight against terrorism (Bryden, Olonisakin, 2010, p. 1).

\section{Theoretical framework: Securitization and counterterrorism in Africa}

The field of security studies has never experienced shortage of theories and paradigms that offer empirical lenses through which myriads of compelling security phenomena and issues could best be studied, understood, and investigated. This brings to fore the indispensability of theories to societal and researchers' quests in proffering workable solutions to societal problems. The end of the Cold War between unarguably the two world's hegemons in the early 1990s opened a new vista in the empirical study of security studies (Burton, 1979). The hitherto state-centric conception of security, that was otherwise known as traditional security, became an area of serious academic interrogations and queries following the rising manifestations of security threats that bordered on the continued survival of humanity itself rather than the human world. Issues such as food security, health security, environmental security, community security, political security, economic security and others, as contained in the 1994 United Nations Development Programme's Working Paper on Human Security, received robust attention from both policy-makers and scholars of security studies (Terriff, 1999). The reasons for this systematic shift to, and emergence of, human security as a corollary of the traditional security are not far-fetched. Firstly, the eventual neutralization and complete eradication of an impending global war, otherwise known as the cold war, that threatened the very basis of global security and continued survival with the potential for a nuclear Armageddon, prompted global agencies and actors into diverting attention to world's pressing needs at this period (1990s upwards). Secondly, the end of the cold war coincided with the time the world was faced with excruciating non-traditional security issues such as poverty, rising global diseases, global financial problems, etc. These, among others, technically aided the ascendancy of the human security lexicon into global prominence.

Still, within the human security argument, the emergence of vigilante groups and community initiative in policing has been placed on the contradictions of globalization, especially its effects on state power and organization of political community (Kuna, 2005, p. 8). Globalization is seen as responsible for widening the level of human insecurity in the southern hemisphere by reinforcing and widening economic, food, health, environmental, personal, community, and political, insecurity (Bilgrin, Morton, 2002, p. 23). Thus, a contestation is observed between globalization as represented by the state with its dominant power expressed as "public power" and the reassertion of local authority (Kuna, 2005, p. 9). Before the eventual recognition of human 
security as an important component of the traditional security system by the United Nations in 1994 (Hough, 2004), Ole Waever, a renowned security scholar, had already interrogated the alternative security approach to the existing traditional security system owing to his intellectual curiosity to understand why some security threats were gaining more attention than the others. This culminated into the incubation of his securitization theory in 1993.

The securitization theory took off from the point of view that security threat that has been successfully securitized would attract more attention and resources than other security threats that have not been securitized. It is a theory that implies that national security policy or action at any point in time is not naturally given but it is to be taken as a careful designation of the securitizing actors in the environment. Sufficed to mean security threats are not simply so until they are so articulated and labeled by the securitizing actors. The securitizing actors here are therefore taken to include the governments, members of the political class and security experts in the area of the security threats. The obvious logic here underscores the primacy of not just labeling act as being a security threat in the securitization process but also indispensability of the speech act. No doubts, Ole Waever's intention in the conception of the securitization theory must have been his burning zest to understand why some obvious security threats and issues had received lesser attention and resources than those less threatening from the securitizing actors such as governments and security experts. Regardless of what Ole's intention might have been, the securitization thesis provides us a very robust theoretical lens to understanding the exigency of the ongoing War on Terror across the African continent, and perhaps the rest of the world.

\section{Counterterrorism in Africa in review}

Basically, the ongoing counterterrorism in Africa is one out of the many concerted efforts of the counterterrorism launched in the wake of the 9/11 bombing of the World Trade Center on the soil of the United States by the International Al-Qaeda terrorist network in 2001. The United Statesled counterterrorism security policy became the launch pad for states across the globe to be brought to speed on the need to domesticate this global security policy given the systematic rise of terrorism across the entire globe. Amid the huge blows dealt on it by terrorism, from the close of the cold war when the focus of international security had shifted from the conventional security (the hard-military style) to the human security system, Africa launched its war on terror security objectives. Having been continually ravaged by the activities of terrorist groups such as Boko Haram (West Africa subregion), Al-Qaeda in the Islamic Maghreb (AQIM) (North Africa region), and the Al-Shabbab, African states began to deploy the hard military option on the counterterrorism operations against the merchants of terrorism within their territories. For instance, the Nigerian government, as other African governments, had been seeking to address and nip the menace of terrorism in the bud, 2009 relying heavily on use of conventional military style approach in addressing Boko Haram terrorism. This has, however, been largely consequential in various regards. Firstly, since Boko Haram terrorism assumed a national and devastating outlook, the Nigerian government has expended more than 100 billion naira in prosecuting its counterterrorism through logistical provisions, military hardware purchases, training and retraining of troops, 
and others. Added to this, human casualty recorded so far has further compounded the negative consequences of the Boko Haram terrorism and Nigeria's conventional counterterrorism. This is in addition to the high casualty figures among troops lost to the counterterrorism. Since 2009, it is estimated that Nigeria has lost more than 1000 soldiers to its counterterrorism. Although the reportage of casualty figures from the Nigeria's counterterrorism has been shrouded in secrecy by the military, an estimation arising from the reported cases of the Boko Haram terrorist attacks in Nigeria since 2009 would reveal a death toll of more than 3000 lives lost, including 680 persons among civilian vigilante group (Premium Times Nigeria, 2017). This is in addition to the damages and disruption the counterterrorism campaign has brought on the socio-economic activities and livelihoods of residents of communities where the counterterrorism is being prosecuted.

The experience has not been different in other African states where the counterterrorism remains in operation. Within the Lake Chad region, Chad, Niger, and Cameroon continue to launch their respective national security backed counterterrorism on Boko Haram. The recent military onslaught against the Boko Haram terrorists along the Chad-Nigeria border along the Borno axis by the Chadian forces, that resulted in deadly casualty on both sides, attested to the military-styled counterterrorism with all its consequences (Akinrinde, 2020). The counterterrorism operations against the Boko Haram terrorists launched by the Chadian forces on 31 March 2020, which was a response to the killing of 92 Chadian troops by the Boko Haram terrorists, resulted in the death of 52 Chadian forces and 1,000 Boko Haram terrorists (Aljazeera News, 2020). Similarly, the Al-Qaeda in the Maghreb (AQIM) continues to disrupt the socio-economic and political space of states within the Maghreb through terroristic killings, bombings, and assassinations. Some of the most persistent and deadliest attacks that had taken place in North Africa, especially in Algeria, which suffered a debilitating civil war in the 1990s, had been prosecuted by AQIM, that also now operate beyond that country's borders, and as far as Iraq.

Furthermore, East Africa has also seen some dramatic terrorists' incidents, aside the bombing of the US embassy and the various terrorist attacks in Mombasa, Kenya, in 1998. In northern Uganda also, the Lord's Resistance Army, which claims fundamentalist Christian views, has systematically used terror methods by murdering, kidnapping, and maiming people within this region.

Similarly, Somalia which has not had a functioning central government since 1991 has aroused the greatest international concern over the strength of armed terrorist groups. A raid by the US commandos on Somalia in September as part of the global counterterrorism, which reportedly killed a suspected Al-Qaeda operative working with one of the Somali factions, further revealed the over-reliance of the counterterrorism in Africa and global counterterrorism on the conventional hard military tactics.

The experiences have not been different in Southern Africa on the counterterrorism. Whilst this sub-region has so far seen little terrorist action, apart from some bombings in South Africa, some of them by right-wing domestic groups, the counterterrorism by governments within this sub-region has largely been premised on the conventional military-styled approach.

It is noteworthy, however, that while the face-to-face combat tends toward swift military success, counterinsurgency is far more cumbersome because the defeated group often proliferate into smaller franchises. The experiences from other parts of the world confirmed this, thus, the 
conventional war in Iraq against Saddam Hussein regime metamorphosed into guerrilla warfare with fragmented terrorist groups. This is evident in the rise of Islamic State of Iraq and the Levant (ISIL) under the leadership of Abu Musab Al-Zarqawi, Islamic State of Iraq and Syria under the leadership of Abu Bakr al-Baghdadi, and several others throughout the Middle-East (Nagl et al., 2008). Shortly after the United States and the allies declared victory in Operation Iraqi Freedom it was dragged into a new phase (hybrid war) of war.

A striking and yet dangerous issue at stake is how to combat Islamic terrorism while maintaining peaceful relationships with law-abiding Muslims (Huntington, 2011). This concern has prompted policy makers to modify strategies to include the strategies of soft-power (Mattern, 2005 , p. 586). Hence, the allied forces policy makers based on the expert advice of combat officers including Generals Petraeus and McChrystal shifted the focus from conventional warfare needing purely military might to counterterrorism or counterinsurgency. This underscores the emerging paradigmatic shift in international political arena from reliance on hard power to soft power to achieve optimal cooperation.

Again, one can observe that the USled response to terrorism in Africa signal an increased militarization of the continental space. Thus, continued attack on root causes of terror and violence, which includes poverty, authoritarianism, discrimination, weak states, and similar conditions, will effectively combat such threats. Any strategy that relies heavily on security (excluding human security) will encourage authoritarianism and undermine African's move towards good governance (Mudasiru, 2011, p. 94).

\section{From counterterrorism to policing terrorism: Prospects for alternative security culture}

The fallouts of the reliance on the use of the conventional security culture or system in the implementation and prosecutions of counterterrorism and global counterterrorism have been grave, unimaginably consequential, and contemporarily counter-productive in the face of global paradigm shift from conventional security culture and approach to the human security idea. It is equally essential for governments and international agencies to better engage African civil society and community groups. Too often African leaders tend to regard counter-terrorism activities as an exclusive responsibility of governments, while security forces frequently treat information about them as "top secret." As a result, governments needlessly exclude "a valuable source of information: the broad public," and make it harder to establish public trust in official efforts (Pillay, 2008, p. 93).

Thus, unlike the inherently coercive approach of hard power for securing compliance, soft power employs cultural and ideological attractions to build cooperation. The underpinning rationale is that peaceful coexistence can easily be forged around cultural, informational, educational, and ideological elements or relationship rather than hegemonic struggle (Enayat, 2005). Furthermore, how can the state secure the cooperation of lawful Islamic leaders in its covert operations? The lessons learned from the post-9/11 attack is that counterterrorism can no longer be a conventional war between terrorists and the armed forces. This, therefore, finds footing in the United 
Nations' global strategy on counterterrorism, which supports greater civil society involvement such as the African civil society groups, vigilant and community based security networks, in opening up counterterrorism initiatives in Africa.

In sum, the integration of all the branches of the military and the non-military, or paramilitary, security agencies is as significant as the integration of the military and the security agencies with the civilian groups whose roles are crucial to successful combat against the terrorist groups. It is significant to note that terrorist groups are able to penetrate the society by identifying the laxities of government and community leaderships and providing or promising to provide some vital socio-economic assistances that the citizens, especially the poor and unemployed, desperately need (Collins, 2004).

Therefore, the notion of counterterrorism as war has often led to failure in addressing them. Terrorism should thus be seen as a crime, a particularly scary type of crime, but a crime nonetheless. When it comes to crime, the best actors to combat it are police (Gurski, 2018, p. 15). And for police efforts to succeed, it must be based on intelligence gathering, involving the people, especially the local communities where the terrorists are operating. Military strategies such as airstrikes, drones, etc. have the unintended consequences of creating more terrorists, as mistakes of killing innocent civilians during airstrikes can lead surviving members of the families to seek revenge by joining terrorist organizations (Gurski, 2018, p. 31). African civil society and community groups can help build support for the efforts of governments on their counterterrorism operations whilst also highlighting the importance of protecting human rights and reaching out to the vulnerable and marginalized within the communities (Akinrinde, 2016, p. 116). Hence, by sharing information with and seeking to engage with civil society, governments are enhancing their security.

If we consider socio-economic and political grievances as sources of insecurity in Africa, including terrorism, then, the continent cannot afford a solely militarist approach to counterterrorism. The contradictions of globalization have manifested in socio-economic and related challenges, depriving large size number of citizens' affordable standard of living. Related to this is contradiction arising from elite factional struggles masked by a recurring ethno-religious and political insecurity which in most cases end up becoming the root cause of terrorism on the continent. This position has been buttressed by scholars including Patterson (1998) who argued that "in the third world countries, insurgencies originate in the grievances of people who are struggling against the monopoly of economic and political power by ruling elite". This is also buttressed by the conclusion of Idowu (1999, p. 74) that these developments (marginalization and the accompanying disaffection and dissatisfaction) "drive the populace into the waiting hands of several groups deriving support from kith-and-kin allegiance and those using religious as mobilization strategy". For instance, such exclusion fueled the emergence of ISIL because Iraq and Syria Sunnis were disaffected from power by the Iraq State regime in Baghdad, and the pro-Iranian Alawite/Shiite regime in Damascus (Cutler, 2017, p. 84).

Again, it was observed concerning America war on terror as it affected Libya in these words: "Libya becomes a mess, a 'shit show' essentially because of the passivity of our European allies, and the obdurate power of tribalism" (Cutler, 2017, p. 143). In other words, tribalism is a strong factor in African politics and society, however, rather than being seen as a negative force, it should 
be made a positive factor as African strength remains its diversity (Omitola, 2018). This can be achieved through inclusive governance and can allow for regional autonomy to stem disaffections that often lead to terrorism. This, therefore, explains the recent move away by some African states from a narrowly militaristic response to human-based security approach. The adoption in 2006 of the UN Global Counter-Terrorism Strategy, coupled with recent realities and human-based security policy actions by most African governments has therefore marked a shift away from a "hard" military style in counterterrorism towards a more nuanced human-based approach that combines concerns over security with the pursuit of development and the promotion of human rights. For instance, the Nigerian government, in realization of the challenges posed by the conventional militaristic approach to its ongoing counterterrorism, decided to accommodate the use of the Joint Civilian Task Force whose aim was to complement the counterterrorism operations, and partner, the Nigerian military in intelligence gathering and other community-based logistics.

Again, as expected, there is now an ongoing debate in the Nigerian legislature on the need to put in place a Commission to oversee the de-radicalization, rehabilitation, and reintegration of the repentant Boko Haram terrorists. This and many newer steps and innovations based on human security, now being introduced into the counterterrorism by African states, has further revalidated Ole Waever's securitization thesis and the indispensability of the human security approach to the success of both the global counterterrorism and counterterrorism in Africa.

Counterterrorism that addresses human security will be sustainable in the long run if it reduces the root conditions such as poverty, alienation, and other factors that often lead people to join terrorist groups in the first instance. It has been observed that if the West could invest in fragile societies like Africa, a dollar spent on development is worth more than that spent fighting a war (Cutler, 2017, p. 143).

\section{Vigilante Group Security and Policing of Terrorism: Prospects in Africa}

One of the recommendations prescribed by the United Nations as a footprint to guiding the on-going counterterrorism across the globe is the accommodation of the human needs and concerns in the prosecution of the counterterrorism. Human needs include recognition of human rights, non-usage of biological or chemical weapon and torture, exclusion of the women and children as targets amongst terrorists, de-radicalization and rehabilitation of repentant terrorists, people-centred strategies and the use of civilian-based organization in intelligence-gathering. This underscores the indispensability and import of a civil and community-owned security group like vigilante in the successful prosecution of the counterterrorism in Africa. Vigilante therefore represents not just a non-state community security apparatus but also a bridge between the government and the host community where the theatre of counterterrorism is on-going. Concisely, the vigilante groups are usually community-based security initiative launched to complement the efforts of the government in providing security to the people, especially those in the rural or peri-urban areas. They are usually licensed by the government of the land through the police force to bear arms in the discharge of their vigilante security responsibilities. Most vigilante groups are therefore formed, and owned communally by communities and usually financed by contributions 
or levies from the community members. Since members of the vigilante security groups are usually indigenes of the community where the vigilante groups operate, it gives the vigilante group leverage in discharging their security responsibilities and complementing the efforts of the government security agencies in banishing security threats while ensuring the protection of lives and properties. Recent studies by Obidiegwu (2019, p. 43), Asif and Weenink (2019, p. 2), Ogbozor (2016), and Kwaja (2014) have given empirical credence to the import and relevance of vigilante security groups as a potent complementary security initiative to the already existing government security agencies like the police and the armed forces. How can the utilities of the vigilante groups be harnessed in the ongoing counterterrorism in Africa? First, the use of civilian or community vigilante group in the on-going counterterrorism in Africa would enable government troops to strengthen the intelligence gathering system. This is basically tied to the fact that every terrorist organization or network is locally, culturally, and communally situated. That is, most terrorist groups and their members have communal, cultural, and geographical origin. For instance, before it grew to become a sub-regional terrorist network, the Boko Haram first started as religious sect in 1995 around the Yobe and Borno states of Nigeria under the name Shabab and it was led by Abubakar Lawan. However, Lawan left to further his studies and this gave Mohammed Yusuf the opportunity of taking over the leadership of the group and during the course of leading the group, Yusuf was alleged to have opened up the group to political influence and popularity. He later built a mosque named Ibn Taymiyyah. And, according to Abolurin (2011), it was in this mosque that Yusuf Mohammed and his then deputy Abubakar Shekau began to build an imaginary state within a state. From this communal root, the Boko Haram grew sporadically to become a sub-regional terrorist group within the West African sub-region known for its cruel bombings, explosions, killing, maiming, and massive destruction, whilst also using religion and violent occultism as weapons of terror in wreaking havoc in Nigeria and the Lake Chad region (Abolurin, 2011). The specific idea here is that since the host communities of terrorist group, their belief system and the cultural and environmental conditions in which they operate are not strange or alien to members of the vigilante group, this strategic and logistical edge would afford government troops leverage in their prosecution of counterterrorism. The International Crisis Group (2011) found out that the:

Benefits of these citizens' task forces or vigilante are manifold. Their knowledge of local languages and terrain, both physical and social, helps security forces better target their operations. Because local civilians have a "better sense of the normal and the abnormal", they can detect threats, such as potential suicide bombers. They can serve as trusted links between security forces and locals. Affiliation with the CJTF can also protect its members from the army and police.

Again, the use of, and perhaps the incorporation of, vigilante groups is capable of reducing the possibility and propensity for human rights violations in local areas where the counterterrorism is being prosecuted. This could be made possible when government troops in concert with the police make use of the local members of the vigilante groups in relating with the people within the host communities on areas such as information or intelligence-tip-off, imposition of curfew on the land, and others. 
The general state of apprehension or fear that readily characterizes civil-military relations in areas where the counterterrorism is taking place would have been eliminated or reduced drastically. Furthermore, experiences in recent time from the ongoing counterterrorism in Nigeria and the Lake Chad region against the Boko Haram terrorists, the Al-Shabbab in Somalia, Al-Qaeda in Maghreb, and the Lord's Resistance Army in Uganda, have shown an emerging initiative that involves the incorporation of the vigilante groups into the non-combative aspects of the African governments' counterterrorism. These are, therefore, the justifications for the imminence of the absorption of the civil and community-based security outfit like the vigilante into the non-combative aspects, mostly the intelligence gathering and logistical aspects, of the ongoing counterterrorism across Africa.

Thus, we foresee a platform for assistance to troops and especially the police in the counterterrorism policing strategy. This strategy in the long run should give way to the type of community policing that can allow people to trust government and reject any promise of alternatives from either terrorists or vigilante outfits.

\section{Challenges to vigilante security practices and policing of terrorism in Africa}

Central to the incorporation and use of the community or civilian-based vigilante security groups is the possible fallout that may arise from the casualty that could be sustained on the part of the vigilante groups. This has been proven, for instance, in the on-going Nigeria's counterterrorism where more than 680 of the Civilian Joint Task Force (CJTV), the Nigerian north-eastern part vigilante group, have been killed in battle (Premium Times Nigeria, 2017). Cities and towns that formed citizen security groups also paid a price, as Boko Haram targeted traditional chiefs and other CJTF supporters. In June 2013, the group declared "all-out war" on the youth of Maiduguri and Damaturu "because they have formed an alliance with the Nigerian military and police to fight our brethren”. Casualties peaked in 2013-2014, due largely to such retribution.

Further, lack of adequate official training and retraining in global best practices for the members of the vigilante on civil responsibilities and roles, expected of them in the on-going counterterrorism, could limit the efficacy of the use and incorporation of the vigilante group into the counterterrorism in Africa. Lack of adequate welfare provisions for the members of the vigilante groups at the heart of the counterterrorism, and for these vigilante members' post-counterterrorism lives may prove costly and render the general idea of vigilantism counterproductive. For instance, the Borno Youths Empowerment Scheme program by the Borno state government in Nigeria offers professional training to the CJTF, but it has been found out that it benefits only a fraction of the whole group, estimated to number between 15,000 and 20,000 in Borno state alone. The Borno State Vigilante and Youth Empowerment Agency Law approved in May 2015 are supposed to facilitate job creation for youth, particularly targeting CJTF members (International Crisis Group, 2017). The governor of Borno has promised to provide about 20,000 jobs to former task force members. So far, these programs and promises have not had much success. Should they not materialise, Nigeria may be left with another angry armed group in the troubled North-East. Some CJTF members allegedly now work for state politicians, who are known to employ thugs to attack 
opponents. Others may move further into extortion, drug trafficking, and other organised criminal activity. Again, if not well coordinated and regulated, vigilante members could also be prone to arbitrariness and human rights abuses. The International Crisis Group has reported that some vigilante members also have exploited their positions for revenge and profit (International Crisis Group, 2017). Few CJTF members receive a stipend; most depend on haphazard support from local authorities, politicians or business people. Others reportedly share with security forces the spoils captured from Boko Haram or receive a portion of the aid provided to IDP camps.

This is the more reason for federal government in Nigeria and governments of other African states to give support to the community policing incorporating the people and vigilante groups in the society. Without the support of the federal government the community policing established by states faces enormous challenges. These include short supply of operational resources, lack of efficient paramilitary and community policing training, lack of equipment and light weapons, potential legitimacy deficit, and conceivable clashes with the police because of lack of cooperation. All of these are recipes for a deepening crisis. Hence, without support from the federal government, the states and regional sponsors of these community policing outfits must envisage taking cognizance of these potential challenges and find achievable means of mitigating them.

One of the ways at ensuring that this strategy becomes effective is to allow for democratic oversight and control of such vigilante outfits. The case of the vigilante outfits of the western part of Nigeria is instructive here. It is purely based on indigenous security architecture of local hunters, night watchmen, private security providers, and community vigilantism; however, these outfits' operations are backed by the laws of the six south-western states in Nigeria that established it. Also, one of the states, Ekiti state, has already established a board to regulate the activities of the vigilante group with an all-important complaints' commission to ensure democratic and public oversight of the security outfit.

\section{Conclusion}

Flowing from our observations and findings, the over-reliance on the conventional security approach or culture in the on-going counterterrorismin Africa has yielded less of the expected results and objectives that informed its adoption. In security terms, it is becoming less and less fashionable as it is turning out to not be in tune with contemporary realities in the globally recommended ideals of human concerns and securities in the prosecution of the counterterrorism. This has therefore informed the innovative idea of the efficacy of civilian or community-based security group like the vigilante in the counterterrorism. The African socio-political, economic, and security histories cannot be divorced from community-based security system such as vigilantism. This, coupled with the efficacy of the vigilante group in intelligence gathering, linguistic, logistical and communal advantages, and know-how in dealing with security threats such as terrorism within a territorial enclave, makes, notwithstanding, its identified teething lapses, the recognition of community-based vigilante group a progressive partner to the government troops and the police in winning the counterterrorism. Such teething lapses can be overcome when there are supports by governments and nongovernmental organisations including international 
organisations to ensure observant of international best practices including regard for human rights. The multiple sources of such assistance will guarantee not only adequate checks on excesses but also reinforce their standing outside direct state and sectarian controls.

\section{Bibliography}

Abolurin, A. (2011). Terrorism in Nigeria and global dimensions. Ibadan: Golden-Gems Unique Multi-Venture.

Akinrinde, O.O. (2016). The use of advertorial curses in soft crime prevention. Annals of Social Sciences, 3 (2), 116.

Akinrinde, O.O. (2020). "Boko Haram Terrorism and the Futurology of Nigeria's Development”. Annals of Spiru Haret University Economic Series, 20 (3), 117-119.

Aljazeera News (2020). Chadian troops kill 1,000 Boko-Haram fighters in Lake Chad. 9 April. Retrieved from: https:// www.aljazeera.com/news/2020/4/9/chadian-troops-kill-1000-boko-haram-fighters-in-lake-chad (26.07.2021).

Asif, M., Weenink, D. (2019). Vigilante rituals theory: A cultural explanation of vigilante violence. European Journal of Criminology, 9, 1-20.

Barash, D.P., Webel, C.P. (2009). Peace and conflict studies. Thousand Oaks, CA: Sage Publications.

Bilgrin, J., Morton, A. (2002). Historicizing representations of failed states: Beyond the cold war annexation of the social sciences. Third World Quarterly, 23 (1), 55-80.

Bryden A., Olonisakin, F. (2010). Conceptualising security sector transformation in Africa. In: A. Bryden, F. Olonisakin (eds.), Security sector transformation in Africa. Geneva Centre for the Democratic Control of Armed Forces.

Burton, J. (1979). Deviance, terrorism and war: The process of solving unsolved social and political problems. New York: St. Martin's Press.

Collins, D. (2004). Spying: The secret history of history. Black Dog and Leventhal Publishers.

Cutler, L. (2017). President Obama's counterterrorism strategy in the war on terror: An assessment. London: Palgrave Macmillan.

Ejiogba, O.A. (2006). African security in the twenty-first century. Nigerian Forum: A Journal of Opinion on World Affairs, September/October, 303.

Enayat, H. (2005). Modern Islamic political thought: The response of the Shia and Sunni Muslims to the twentieth century. Bloomsbury Publishing.

Federal Bureau of Investigations (2020). Terrorism. Washington DC. Retrieved from: https://www.fbi.gov/investigate/ terrorism (26.07.2021).

Gurski, P. (2018). An end to war on terrorism. London: Rowman \& Littlefield Publishers.

Hough, P. (2004). Understanding global security. New York: Routledge.

Huntington, S.P. (2011). The clash of civilization and the remaking of world order. Simon \& Schuster.

Idowu, L. (1999). Citizenship's status, statehood problem and political conflict in Nigeria. Nordic Journal of African studies, 8 (2), 74.

International Crisis Group (2017). Double-edged word: Vigilantes in African counter- insurgencies. Retrieved from: https://www.crisisgroup.org/africa/west-africa/sierra-leone/251-double-edged-sword-vigilantes-africancounter-insurgencies (26.07.2021).

Interpol (2020). Terrorism. Retrieved from: https://www.interpol.int/en/Crimes/Terrorism (26.07.2021).

Kuna, M.J. (2005). African Conflict Profile. Journal of Ethnic and Conflict Studies (CENTECS), 1 (2), 8.

Kwaja, C. (2014). Informal security in Nigeria. Retrieved from: https://secgovcentre.org/2014/04/32581/ (26.07.201)

Lewis, O. (2017). Conceptualising state terrorism. In: S. Romaniuk, F. Grice, D. Irrera, S. Webb (eds.), The Palgrave handbook on global counterterrorism, London: Palgrave, Macmillan.

Mattern, J.B. (2005). Why soft power isn't so soft: Representational force and the sociolinguistic construction of attraction in world politics. Millennium, 33 (3), 583-612.

Mudasiru, S.O. (2011). Understanding the dimensions of the new face of terror: A political economy of African terrorist groups. The Constitution: A Journal of Constitutional Development, 11 (4), 94-106. 
Nagl, J.A., Amos, J.F., Sewall, S., Petraeus, D.H. (2008). The US Army/Marine corps counterinsurgency field manual. University of Chicago Press.

Nye, J. (2004). Soft power: The means to success in world politics. Public Affairs Books.

Obidiegwu, U.J. (2019). The extent vigilante security group collaborates with the police in minimizing crime in ABIA State. IOSR Journal of Research \& Method in Education, 9 (4), 41-45.

Ogbozor, E. (2016). Understanding the informal security sector in Nigeria. Washington: United States Institute of Peace, Special Report.

Omitola, B.O. (2018). African governance and transculturalism: Current challenges and future prospects. In: J. Wieland, J.B. Montecinos (eds.), Sub-Saharan perspectives on transcultural leadership. Marburg: Metropolis-Verlag.

Patterson, O. (1998). Rituals of blood: Consequences of slavery in two American centuries. Washington DC: Civitas/ Counterpoint.

Pillay, D. (2008). Relative deprivation, social instability and cultures of entitlements. In: S. Hassim, T. Kupe, E. Worby (eds.), Go home or die here: Violence, xenophobia and their invention of difference in South Africa. Johannesburg: Wits Press.

Premium Times Nigeria (2017). Boko Haram kills 680 civilian JTF members in three years, July 9. Retrieved from: https://www.premiumtimesng.com/news/headlines/236363-boko-haram-kills-680-civilian-jtf-members-threeyears-official.html (26.07.2021).

Roach, K. (2013). Substitute justice: Challenges to American counterterrorism activities in non-American courts. Mississippi Law Journal, 82, 907-974.

Terriff, T. (1999). Security studies today. Polity Press.

\section{Cytowanie}

Omitola, B., Akinrinde, O.O., Fakoya, V., Tar, U. (2021). Beyond conventional counterterrorism strategy: Prospects and challenges of community and vigilante groups' policing in Africa. Acta Politica Polonica, 2 (52), 27-40. DOI: 10.18276/ap. 2021.52-03. 